\title{
Chemical composition and cellulase-assisted extraction of total saponins from Gomphrena celosioides Mart.
}

\author{
Nguyen Thi Hoang Yen, Le Pham Tan Quoc* \\ Institute of Biotechnology and Food Technology, Industrial University of Ho Chi Minh City, Ho Chi Minh City, Vietnam
}

\begin{abstract}
The major purpose of the present study was to determine the chemical composition of dried Gomphrena celosioides Mart., including crude protein, lipid, total sugar, reducing sugar, ash, crude fiber, moisture, crude pectin, and total saponins in particular. This plant contains a large percentage of total saponins, which are widely used in food technology and pharmaceutical industries. In our study, the conditions for the extraction of total saponins from the plant were optimized, with special focus on cellulase concentration, $\mathrm{pH}$, hydrolyzation time, and temperature. The highest amount of total saponins content (TSC) was $1.550 \pm 0.016 \%$ under optimal extraction conditions (cellulase concentration: $0.7 \%(\mathrm{v} / \mathrm{w})$, hydrolyzation time: $4 \mathrm{~h}$, hydrolyzation temperature: $60^{\circ} \mathrm{C}$, and $\mathrm{pH}$ value: 5 ). Accordingly, the total saponins from $G$. celosioides Mart. were easily extracted.
\end{abstract}

Key words: bioactive compounds, composition, enzyme, extraction, Gomphrena celosioides Mart.

\section{Introduction}

Gomphrena celosioides Mart. belongs to the Amaranthaceae family and occurs primarily in the temperate climates of Asia, South America, and East and West Africa. It is found along riverbanks, roadsides, or on fallow lands (Onocha et al., 2005). In Vietnam, G. celosioides is considered as a wild herbal plant, and it has diverse pharmacological properties and high medicinal values because it is a rich source of bioactive compounds (Thuy et al., 2020b). Many studies have indicated that this herbal plant contains, among others, essential oils (Tiwari et al., 2014), saponins, flavonosides, anthocyanosides, and coumarin derivatives (Ogundipe et al., 2008). Furthermore, it has many benefits for human health, as it exhibits antibacterial, anticancer, and analgesic effects (Esmat and Mittapally, 2020). In folk medicine, it has been used to prevent diseases such as diarrhea and as an antiurolithiatic agent (Nandini et al., 2018). Other biological activities of saponins extracted from this plant include anthelmintic and cytotoxic activities (Onocha et al., 2005) and diuretic effects (Vasconcelos et al., 2017).

Triterpenoid saponins are bioactive compounds from G. celosioides and are glycosides with foaming capacity
(Mamta and Jyoti, 2012); they consist of 30 carbon aglycones and are widely distributed in plants (Balanites aegyptiaca, Brazilian ginseng, Safed musli, etc.) within their various structures (fruit mesocarp, seed, and root) (Chapagain and Wiesman, 2008; Bitencourt et al., 2014; Deore et al., 2015). On the basis of the results of several studies, saponins have been flagged as important compounds that possess many biological activities, including the capability to inhibit tumor cell proliferation in mice (Gauthier et al., 2009) and lower blood cholesterol and triacylglycerol levels in Zucker rats (Megalli et al., 2006). In addition, saponins isolated from medicinal plants have antiobesity effects (Marrelli et al., 2016), and they are natural surfactants and emulsifiers and are widely used in cosmetics and food products (Oleszek and Hamed, 2010). The extraction of total saponins from plants is, however, a huge challenge for scientists because of their poor stability in extraction conditions $(\mathrm{pH}$, temperature, time, liquid-solid ratio) (Liu et al., 2016) and structural variety arising from different substituents $\left(\mathrm{OH}, \mathrm{CH}_{3}\right.$, or $\mathrm{COOH}$ ) on the aglycone moieties (Li et al., 2006).

In recent years, many studies have demonstrated that saponins from plants could be isolated by different me- 
thods. For instance, Le et al. (2018) optimized the extraction parameters to isolate the highest total saponins content (TSC) from the seeds of Gac (Momordica cochinchinensis Spreng.) by microwave-assisted extraction (MAE), while Hierro et al. (2018) extracted saponins from quinoa, lentil, fenugreek, soybean, and lupin by ultrasound-assisted extraction (UAE). Other extraction methods such as supercritical fluid (Bitencourt et al., 2014), Soxhlet, and maceration extraction (Deore et al., 2015) have also been used to extract saponins. However, most of these extraction methods are not environmentally friendly because of the following disadvantages: consumption of large amounts of organic solvents, high energy requirements, low extraction yields, and overall high cost of the process (Marathe et al., 2017).

Presently, the enzyme-assisted extraction (EAE) method is considered as a green, modern, and popular method that can overcome the aforementioned disadvantages. To the best of our knowledge, to date, there have been no studies on cellulase-assisted extraction (CAE) of total saponins from $G$. celosioides. In the present study, the chemical composition of $G$. celosioides and the effects of single extraction parameters, including cellulase concentration, $\mathrm{pH}$, hydrolyzation time, and temperature on TSC were investigated.

\section{Materials and methods}

\section{Plant material and sample preparation}

Fresh $G$. celosioides plants were collected from the $\mathrm{Cu}$ Chi district, Ho Chi Minh City (Vietnam), and their heights ranged from 30 to $40 \mathrm{~cm}$. No physical damage and no pest contamination were observed on the plants. The specimens were packed in a polyethylene $(\mathrm{PE}) \mathrm{bag}$, preserved at $4{ }^{\circ} \mathrm{C}$, and transported to the laboratory. The samples were first cleaned under tap water, drained, and dried at $60^{\circ} \mathrm{C}$ until the moisture content was less than $13 \%$. They were then ground by a grinder (Panasonic MXV310KRA, China) for 5 min and separated with a sieve (hole diameter: $2 \mathrm{~mm}$ ) to collect the specimens that could pass through. Subsequently, the obtained samples were packed in a PE bag and preserved at $4{ }^{\circ} \mathrm{C}$. These samples were used for all the subsequent experiments.

\section{Chemicals and reagents}

Cellulase with enzymatic activity of 700 EGU/g derived from Trichoderma reesei was purchased from Novo- zymes (Denmark). Oleanolic acid was provided by Sigma (Germany) and used as a standard reagent. All other chemicals were purchased from Sigma (Germany) and were of analytical reagent grade.

\section{Cellulase-assisted extraction (CAE)}

The dried powdered sample ( $2 \mathrm{~g}$ ) was used to extract total saponins in $50 \mathrm{ml}$ of distilled water with cellulase. The TSC of samples was determined under different extraction conditions, including cellulase concentrations $(0.4,0.5,0.6,0.7,0.8$, and $0.9 \%, \mathrm{v} / \mathrm{w})$, hydrolyzation times $(1,2,3,4,5$, and $6 \mathrm{~h})$, hydrolyzation temperatures $\left(40,45,50,55,60,65\right.$, and $\left.70^{\circ} \mathrm{C}\right)$, and $\mathrm{pH}$ values $(4,4.5$, $5,5.5$, and 6 , using $2.8 \mathrm{M}$ citric acid to adjust $\mathrm{pH})$. After the reactions, the mixtures were rapidly heated at $100^{\circ} \mathrm{C}$ to inactivate cellulase. The extracts obtained were immediately cooled to room temperature using an ice water bath and were then filtered through a Whatman filter paper (No. 4) under vacuum to remove the residues. The extracts were then analyzed to determine the amount of TSC.

\section{Determination of the chemical composition of $G$. celosioides samples}

Moisture, ash, crude fiber, crude protein, total lipid, and total sugar contents were determined according to AOAC 934.01, AOAC 923.03, AOAC 962.09, AOAC 978.04, AOAC 920.39, and AOAC 968.28, respectively (Horwitz, 2000). The reducing sugar content was estimated by the Miller method (Miller, 1959).

\section{Determination of crude pectin content in G. celosioides samples}

Pectin was extracted according to the method of Quoc (2019) with slight modifications. Five grams of sample were extracted by MAE under the following extraction conditions: oxalic acid solution as the extraction solvent (concentration of $0.25 \%$ ), solid-to-solvent ratio of $1: 39(\mathrm{w} / \mathrm{v})$, extraction time of $9 \mathrm{~min}$, and irradiation power of $660 \mathrm{~W}$. The mixture was then cooled to room temperature and filtered using a filter fabric. Next, $96 \%$ ethanol solution was used to precipitate the pectin (the pectin solution-to-alcohol ratio was $1: 3$, v/v) for $60 \mathrm{~min}$. The ethanol mixture was filtered off, and the precipitate was collected. The obtained pectin was dried at $70^{\circ} \mathrm{C}$ until its moisture content was less than $10 \%$. The percent yield of crude pectin was calculated using the following formula: 


$$
\text { Crude pectin }[\%]=\frac{m_{2} \times 100}{m_{1}}
$$

where $m_{1}(\mathrm{~g})$ is the mass of the initial sample and $m_{2}(\mathrm{~g})$ is the mass of crude pectin obtained.

\section{Determination of TSC in the extracts}

The amount of TSC in the extracts was determined according to the method of Chen et al. (2007) with minor changes. First, the volume of the extract was increased to $100 \mathrm{ml}$ with distilled water. Then, $2 \mathrm{ml}$ of the diluted extract was placed in a test tube and warmed in boiled water. Subsequently, $0.2 \mathrm{ml}$ of $8 \%$ (w/v) vanillin-acetic acid solution and $1.2 \mathrm{ml}$ of perchloric acid were added to the extract. The mixture was vigorously stirred and incubated in a water bath at $60^{\circ} \mathrm{C}$ for $45 \mathrm{~min}$. A violet color was observed as a result of the reaction. The ethyl acetate solution was added to this mixture to a total volume of $5 \mathrm{ml}$. After cooling to room temperature, the absorbances of the samples were recorded at $550 \mathrm{~nm}$ with a spectrophotometer (Genesys 20, USA) with a blank solution as a reference. In addition, oleanolic acid was also prepared and used to construct the standard curve. Finally, the result was expressed as gram oleanolic acid equivalents per $100 \mathrm{~g}$ of dry weight (\%).

A standard curve was constructed as follows to determine the saponin content in the prepared samples. Different volumes $(0,0.05,0.10,0.15,0.20,0.25$, and $0.30 \mathrm{ml}$ ) of $2000 \mathrm{ppm}$ oleanolic acid were transferred into the test tubes. Next, $0.2 \mathrm{ml}$ of $8 \%$ (w/v) vanillinacetic acid solution and $1.2 \mathrm{ml}$ of perchloric acid were added to the test tube, and ethyl acetate was added to a final volume of $5 \mathrm{ml}$. Absorbance of the prepared solutions was measured at $550 \mathrm{~nm}$ with a spectrophotometer. The linear relationship of saponins content and absorbance was presented by the following regression equation:

$$
y=0.0386 x+0.1575\left(R^{2}=0.98\right),
$$

where $x(\mathrm{ppm})$ is the amount of TSC in the solution for the colorimetric analysis and $y$ is the absorbance at $550 \mathrm{~nm}$.

\section{Data analysis}

All analyses were performed in triplicate, and the results were evaluated by one-way analysis of variance (ANOVA) using Statgraphics software (Centurion XV). Differences were considered to be significant at
$P \leq 0.05$, and Fisher's least significant difference (LSD) test was performed to establish significant differences.

\section{Results and discussion}

\section{Determination of the components of fresh and dried G. celosioides}

The determination of the chemical composition of $G$. celosioides is quite important, as the nature of composition can play a main role in selecting the optimum extraction method. Table 1 shows that protein, lipid, sugar, fiber, ash, and pectin were present in both fresh and dried samples.

Table 1. The main components of the fresh and dried $G$. celosioides

\begin{tabular}{c|l|c|c}
\hline No & $\begin{array}{c}\text { Chemical } \\
\text { components }\end{array}$ & $\begin{array}{c}\text { Content } \\
\text { in fresh material } \\
{[\%]}\end{array}$ & $\begin{array}{c}\text { Content } \\
\text { in dried material } \\
{[\%]}\end{array}$ \\
\hline 1 & moisture & $76.767 \pm 0.107$ & $12.903 \pm 0.091$ \\
\hline 2 & crude protein & $3.519 \pm 0.060$ & $14.470 \pm 0.026$ \\
\hline 3 & lipid & $2.139 \pm 0.131$ & $7.868 \pm 0.094$ \\
\hline 4 & reducing sugar & $0.629 \pm 0.002$ & $2.480 \pm 0.030$ \\
\hline 5 & total sugar & $3.290 \pm 0.073$ & $12.140 \pm 0.066$ \\
\hline 6 & crude fiber & $6.087 \pm 0.003$ & $27.890 \pm 0.133$ \\
\hline 7 & crude pectin & $2.953 \pm 0.129$ & $12.083 \pm 0.045$ \\
\hline 8 & ash & $1.870 \pm 0.044$ & $7.888 \pm 0.013$ \\
\hline
\end{tabular}

The moisture content of the fresh plant was quite high $(76.767 \%)$, similar to that of other herbal plants or vegetables such as Polygonum multiflorum Thunb. root (78.6\%) (Quoc and Muoi, 2015), leek (Allium porrum) (83\%), parsnip (Pastinaca sativa) (79.53\%), and potato (Solanum tuberosum) (75\%) (Butnariu and Butu, 2014). However, only $12.903 \%$ moisture was detected in the dried plant in this study, which helped to preserve the samples over a long time period. Further, the total protein, lipid, ash, sugar, pectin, and reducing sugar content in the dried materials were very high: $14.470,7.868$, $7.888,12.140,12.083$, and 2.480, respectively (Table 1). These results indicated that the drying process did not significantly affect the composition of the initial sample, and consequently, the dried $G$. celosioides plant was nutritious; contained various essential compounds for health, such as carbohydrates, proteins, and lipids; and created favorable conditions for storage. 
In the EAE method, plant cell components such as cellulose, protopectins, lipids, and proteins dramatically affect the compositions of the extracts and extraction yields (Puri et al., 2012). Therefore, the use of enzymes, which degrade cell walls to extract bioactive substances from plant cells, is a popular practice (Wijesinghe and Jeon, 2012). In the present study, the total fiber content was quite high $(27.890 \%)$ when compared with other components such as pectins (12.083\%), lipids (7.868\%), and proteins (14.470\%). Thus, choosing appropriate extraction conditions for cellulase activities is important to obtain a high content of saponins in the extracts.

\section{Effect of the cellulase enzyme concentration on TSC extraction}

Cell wall components act as a deterrent to the extraction of biologically active compounds from plants. Therefore, the use of certain enzymes to degrade cell wall polymers is an effective step that has been widely used for some plant species. Cellulase, which catalyzes the breakdown of cellulose to glucose (Puri et al., 2012), is commonly used for the extraction of biological compounds (Qian, 2014).

For enzymatic reaction, some factors such as the enzyme-to-substrate ratio, the type of solvent used, and the reaction conditions ( $\mathrm{pH}$, temperature, etc.) are important parameters (Wijesinghe and Jeon, 2012). Figure 1 shows the influence of different cellulase concentrations on the amount of TSC in the extracts; the extraction parameters (water-to-dried material ratio of $25: 1(\mathrm{ml} / \mathrm{g})$, extraction temperature of $45^{\circ} \mathrm{C}$, extraction time of $2 \mathrm{~h}$, and $\mathrm{pH}$ of 4.5) remained unchanged. The results indicated a significant increase in the quantity of TSC obtained in the extracts as the cellulase concentration increased from 0.4 to $0.7 \%$. However, the amount of TSC obtained did not change with higher enzyme concentrations $(0.8$ and $0.9 \%$ - Figure 1 . Furthermore, the amount of TSC gained was remarkably different in extracts with various cellulase concentrations $(P<0.05)$, except for specimens with added enzyme concentrations of $0.7,0.8$, and $0.9 \%$. Increasing the enzyme concentration to a certain value resulted in an increased yield of the product in the extract to the maximum value. Beyond this concentration, the yield did not change significantly $(0.931$ and $0.916 \%$ for 0.8 and $0.9 \%$ enzyme concentration, respectively). This might be because the TSC in the plant was completely extracted. Therefore, an enzyme concentration of $0.7 \%$ was chosen for the following experiments.

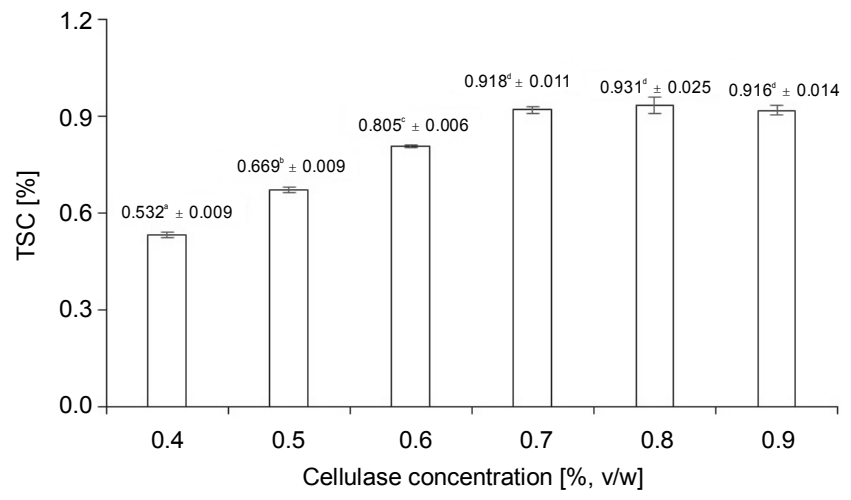

Fig. 1. TSC of extracts at various cellulase concentrations (different letters showed significant differences at level of 0.05)

\section{Effect of pH on TSC extraction}

One of the most critical factors in enzymatic extraction is $\mathrm{pH}$, which significantly affects enzymatic reaction rates. The optimum enzyme-catalyzed activity is achieved at the most favorable $\mathrm{pH}$ value for the enzyme (Wijesinghe and Jeon, 2012). Figure 2 shows the effect of solvent extraction at different $\mathrm{pH}$ values on the amount of TSC when the other extraction parameters were kept constant (water-to-dried material ratio of $25 \mathrm{ml} / \mathrm{g}$, enzyme concentration of $0.7 \%$, extraction temperature of $45^{\circ} \mathrm{C}$, and extraction time of $2 \mathrm{~h}$ ).

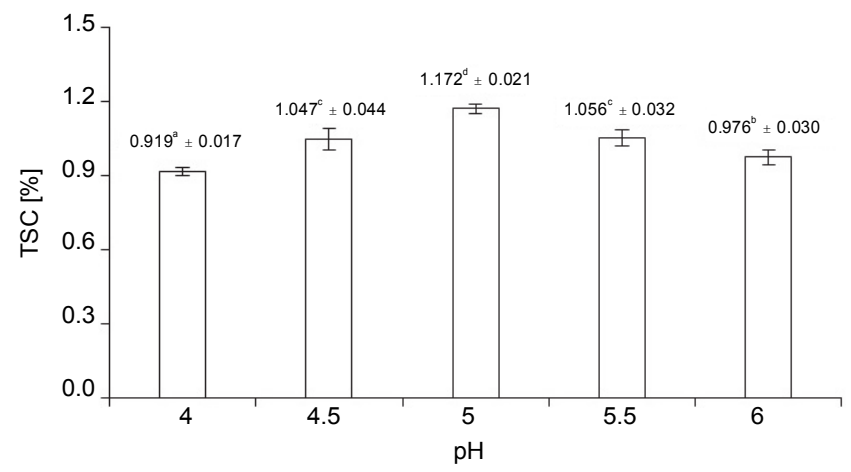

Fig. 2. TSC of extracts at various $\mathrm{pH}$ values (different letters showed significant differences at level of 0.05 )

As pH increased from 4 to 5, the amount of TSC extracted also increased to the maximum of $1.172 \%$. Subsequently, the quantity of TSC obtained in the extracts reduced steadily with higher $\mathrm{pH}$ values (Fig. 2). The optimal $\mathrm{pH}$ determined in this study ( $\mathrm{pH}$ ) was slightly different from that reported in other studies; this is because of differences in plant species and the enzyme (cellulase) used, for example Qian (2014) extracted polysaccharides from dried pumpkin (Cucurbita mo- 
schata) with the following optimum CAE conditions: extraction time of $40 \mathrm{~min}$, extraction temperature of $55^{\circ} \mathrm{C}$, and $\mathrm{pH}$ of 4.5 . On the other hand, the results of the present study are similar to those reported by Liu et al. (2010), who extracted diosgenin from yellow ginger (Dioscorea zingiberensis) with the CAE method (cellulase derived from Trichoderma viride, $15000 \mathrm{U} / \mathrm{g}$ ) at $55^{\circ} \mathrm{C}$, $\mathrm{pH}$ value of 5 , and the enzyme-to-substrate ratio of $15 \times 10^{3} \mathrm{U} / \mathrm{g}$. Thus, on the basis of the obtained results, a $\mathrm{pH}$ value of 5 was selected for the subsequent experiments performed in this study.

\section{Effect of the extraction temperature on TSC extraction}

The temperature recommended for most extractions of bioactive compounds from plants is usually less than $70^{\circ} \mathrm{C}$, as bioactive constituents easily degrade at high temperatures (Liu et al., 2016). The effect of temperature on the quantity of the extracted TSC is shown in Figure 3. The extraction process was conducted under the following conditions: the water-to-dried sample ratio of $25 \mathrm{ml} / \mathrm{g}$, $\mathrm{pH}$ value of 5 , enzyme concentration of $0.7 \%$, and time of $2 \mathrm{~h}$. As the temperature increased from 40 to $60^{\circ} \mathrm{C}$, the amount of TSC obtained in the extracts grew moderately, up to $1.441 \%$. Then, the level of TSC extracted decreased dramatically to $1.217 \%$ when the extraction temperature increased to $70^{\circ} \mathrm{C}$.

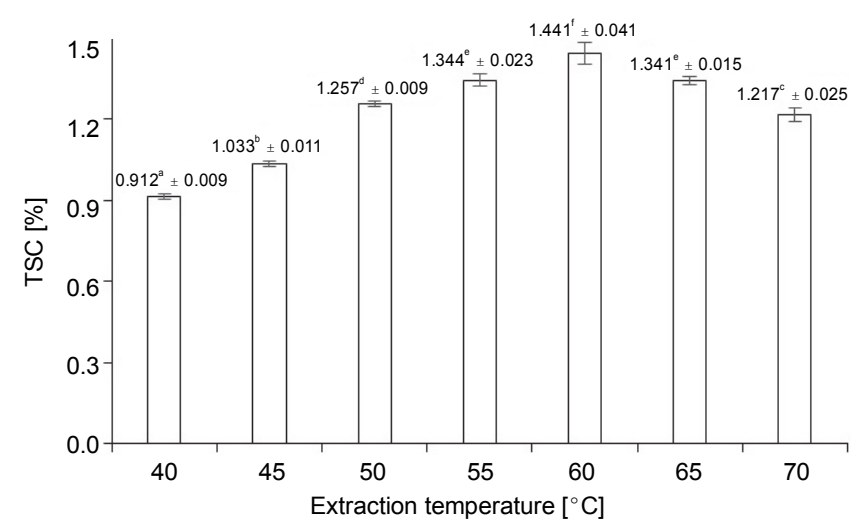

Fig. 3. TSC of extracts at various extraction temperatures (different letters showed significant differences at level of 0.05)

These results can be explained by the fact that the rate of the enzyme-catalyzed reaction increases as temperature increases. Furthermore, the increase in temperature causes a decline in the viscosity of the medium. Consequently, the interaction between the substrate and the enzyme occurs easily, which facilitates a faster mass transfer rate (Dai and Mumper, 2010). However, higher temperatures also cause an adverse impact on the stability of the enzyme, leading to its inactivation (Wijesinghe and Jeon, 2012). Furthermore, a high temperature stimulates the decomposition of compounds, especially bioactive compounds such as polyphenols and saponins (Dai and Mumper, 2010).

In the present study, an extraction temperature of $60^{\circ} \mathrm{C}$ was selected for all the subsequent experiments (determination of the extraction time). The optimal extraction temperature determined in the present study was slightly higher than that reported by Huy et al. (2019) who extracted triterpenoid saponins from the dried root and leaf of Pseuderanthemum palatiferum (Nees) Radlk at $55^{\circ} \mathrm{C}$ by viscozyme-assisted extraction (viscozyme is a multienzyme complex containing a wide range of carbohydrases, including arabanase, cellulase, $\beta$-glucanase, hemicellulase, and xylanase). In addition, the optimal extraction temperature determined in the present study was also significantly higher than that reported by Pan and $\mathrm{Wu}$ (2014), who used the CAE method to extract polysaccharides from garlic at $45^{\circ} \mathrm{C}$. These results indicated that cellulase used in this study possessed a good heat resistance capacity. Moreover, the optimal temperature of enzyme-aided extraction significantly depends on the type of enzyme and plant species.

\section{Effect of the extraction time on TSC extraction}

Figure 4 illustrates the effect of the extraction time on the amount of TSC obtained in the extract while other extraction parameters were maintained as follows: water-to-dried sample ratio of $25 \mathrm{ml} / \mathrm{g}$, enzyme concentration of $0.7 \%$, extraction temperature of $60^{\circ} \mathrm{C}$, and $\mathrm{pH}$ value of 5 . The results showed that the highest TSC obtained was $1.550 \%$ with an extraction time of $4 \mathrm{~h}$. The TSC decreased to $1.298 \%$ with a longer extraction time $(6 \mathrm{~h})$. Saponins and cellulase enzymes are heat-sensitive compounds; hence, they degrade easily with exposure to high temperatures over long periods of time. These results demonstrate that the extraction time is an extremely important factor in the efficiency of cellulase activities (Wijesinghe and Jeon, 2012; Rostami and Gharibzahedi, 2017). The amount of TSC obtained in this study was higher than that obtained by Chen et al. (2007) who isolated total saponins from Ganoderma atrum by the MAE method with the highest yield of $0.968 \%$. However, 


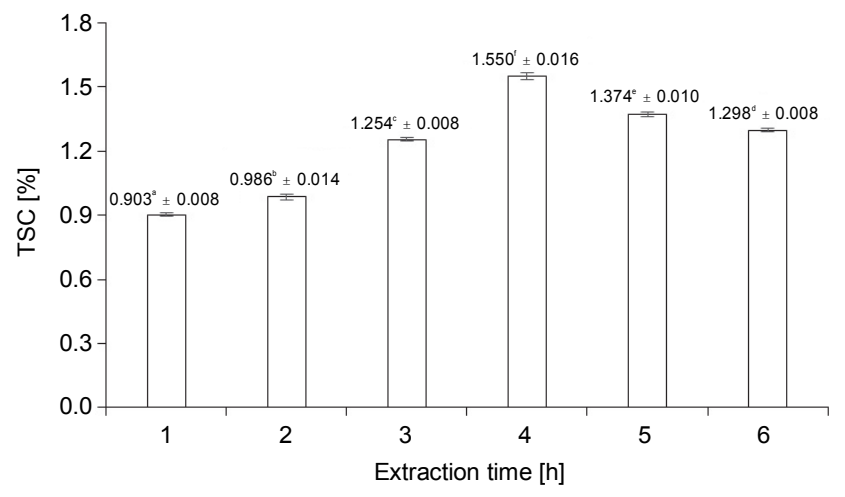

Fig. 4. TSC of extracts at various extraction times (different letters showed significant difference at level of 0.05)

the amount of TSC obtained in the present study was lower than that obtained by $\mathrm{Hu}$ et al. (2012), who extracted total saponins from Eclipta prostrasta L. using the UAE method (2.096\%). These results indicate that the quantity of TSC obtained in the extract was strongly affected by the extraction methods and plant species.

Further, the optimal extraction time determined in the present study $(4 \mathrm{~h})$ was significantly shorter than that of Chang et al. (2009), who used the enzyme Cellulase-12T (3.67\%) to extract 20(S)-ginsenoside $\mathrm{Rg}_{3}$ from a white ginseng extract for over $72 \mathrm{~h}$. In contrast, the extraction time in our study was significantly longer than that reported by Thuy et al. (2020a), who took only 40 min to extract total saponins from Polyscias fruticosa (L.) Harms. leaves with the CAE method. These varied extraction conditions could also be due to different types of saponins and cellulase. Therefore, in the present study, on the basis of the abovementioned results, a $4 \mathrm{~h}$ time was chosen for the extraction of total saponins from dried $G$. celosioides. In general, by using $\mathrm{CAE}$ under the optimum extraction conditions, we isolated saponins from G. celosioides, and this plant can be used as the abundant source of saponins.

\section{Conclusions}

The $G$. celosioides plant used in this study contains a variety of chemical compounds, which include essential compounds, especially saponins. This bioactive compound was successfully extracted from dried G. celosioides plant by the CAE method, with the yield of $1.550 \%$ TSC. All extraction parameters strongly affected the yield of saponins. The best parameters to extract saponins were as follows: cellulase concentration of $0.7 \%, \mathrm{pH}$ value of 5 , extraction temperature of $60^{\circ} \mathrm{C}$, and extraction time of $4 \mathrm{~h}$. These results highlight that the G. celosioides plant seems to be a cheap and abundant source of saponins for food or pharmaceutical industries in the future.

\section{Acknowledgments}

The authors would like to express their gratitude to Dr. Phan Thuy Xuan Uyen for sharing the pearls of wisdom during the course of this research. The authors would like to thank all members of the laboratory for their support.

\section{References}

Bitencourt R.G., Queiroga C.L., Junior I.M., Cabral F.A. (2014) Fractionated extraction of saponins from Brazilian ginseng by sequential process using supercritical $\mathrm{CO}_{2}$, ethanol and water. J. Supercrit. Fluids 92: 272-281.

Butnariu M., Butu A. (2014) Chemical composition of vegetables and their products. [in:] Handbook of food chemistry. Ed. Cheung P., Berlin, Springer: 1-49.

Chang K.H., Jee H.S., Lee N.K., Park S.H., Lee N.W., Paik H.D. (2009) Optimization of the enzymatic production of 20(S)-ginsenoside $\mathrm{Rg}_{3}$ from white ginseng extract using response surface methodology. New Biotechnol. 26(3-4): $181-186$.

Chapagain B.P., Wiesman Z. (2008) Metabolite profiling of saponins in Balanites aegyptiaca plant tissues using LC (RI)ESI/MS and MALDI-TOF/MS. Metabolomics 4: 357-366.

Chen Y., Xie M.Y., Gong X.F. (2007) Microwave-assisted extraction used for the isolation of total triterpenoid saponins from Ganoderma atrum. J. Food Eng. 81(1): 162-170.

Dai J., Mumper R.J. (2010) Plant phenolics: Extraction, analysis and their antioxidant and anticancer properties. Mol. 15: 7313-7352.

Deore S.L., Baviskar B.A., Rangari A.S. (2015) Rapid and high yield extraction method for saponins from Safed musli. Pharmacogn. J. 7: 210-214.

Esmat A.U., Mittapally S. (2020) A review on Gomphrena globosa (L). Int. J. Res. Ayurveda Pharm. 11(3): 78-84.

Gauthier C., Legault J., Girard-Lalancette K., Mshvildadze V., Pichette A. (2009) Haemolytic activity, cytotoxicity and membrane cell permeabilization of semi-synthetic and natural lupane- and oleanane-type saponins. Bioorg. Med. Chem. 17(5): 2002-2008.

Hierro J.N., Herrera T., García-Risco M.R., Fornari T., Reglero G., Martin D. (2018) Ultrasound-assisted extraction and bioaccessibility of saponins from edible seeds: quinoa, lentil, fenugreek, soybean and lupin. Food Res. Int. 109: 440-447.

Horwitz W. (2000) Official methods of analysis of AOAC International. Gaithersburg, Md: AOAC International.

Hu T., Guo Y.Y., Zhou Q.F., Zhong X.K, Zhu L., Piao J.H., Chen J., Jiang J.G. (2012) Optimization of ultrasonic-assisted extraction of total saponins from Eclipta prostrasta $L$. using response surface methodology. J. Food Sci. 77(9): 975-982. 
Huy T.B., Phuong N.T.L., Nga B.K., Oanh H.N., Hieu N.H. (2019) Enzyme-assisted extraction of triterpenoid saponins from Pseuderanthemum palatiferum (Nees) Radlk. dry leaf powder and bioactivities examination of extracts. Biol. Chem. Chem. Biol. 4: 8129-8134.

Le A.V., Parks S.E., Nguyen M.H., Roach P.D. (2018) Optimisation of the microwave-assisted ethanol extraction of saponins from Gac (Momordica cochinchinensis Spreng.) seeds. Med. 5(3): 70-83.

Li B., Abliz Z., Tang M., Fu G., Yu S. (2006) Rapid structural characterization of triterpenoid saponins in crude extract from Symplocos chinensis using liquid chromatography combined with electrospray ionization tandem mass spectrometry. J. Chromatogr. A 1101: 53-62.

Liu W., Huang W., Sun W.L., Zhu Y.L., Ni J.R. (2010) Production of diosgenin from yellow ginger (Dioscorea zingiberensis $C$. H. Wright) saponins by commercial cellulase. World J. Microbiol. Biotechnol. 26: 1171-1180.

Liu Y., Li Z., Xu H., Han Y. (2016) Extraction of saponin from Camellia oleifera Abel cake by a combination method of alkali solution and acid isolation. J. Chem. ID 6903524: $1-8$.

Mamta S., Jyoti S. (2012) Phytochemical screening of Acorus calamus and Lantana camara. Int. Res. J. Pharm. 3: 324-326.

Marathe S.J., Jadhav S.B., Bankar S.B., Singhal R.S. (2017) Enzyme-assisted extraction of bioactives. [in:] Food bioactives - extraction and biotechnology applications. Ed. Puri M. Switzerland, Springer International Publishing AG: 171-201.

Marrelli M., Conforti F., Araniti F., Statti G.A. (2016) Effects of saponins on lipid metabolism: a review of potential health benefits in the treatment of obesity. Mol. 21(10): 1404.

Megalli S., Davies N.M., Roufogalis B.D. (2006) Antihyperlipidemic and hypoglycemic effects of Gynostemma pentaphyllum in the Zucker fatty rat. J. Pharm. Pharm. Sci. 9: 281-291.

Miller G. (1959) Use of dinitrosalicylic acid reagent for determination of reducing sugar. Anal. Chem. 31: 426-428.

Nandini K.N., Palaksha M.N., Gnanasekaran D. (2018) A review of Gomphrena serrata. Int. J. Sci. Res. Methodol. 11(1): 104-110.

Ogundipe O.T., Ajayi G., Adeyemi T.O. (2008) Phytoanatomical and antimicrobial studies on Gomphrena celosioides Mart. (Amaranthaceae). Hamdard Med. 51(3): 146-156.

Oleszek W., Hamed A. (2010) Saponin based surfactants. [in:] Surfactants from renewable sources resources. Ed. Kjellin M., Johansson I. Chichester, John Wiley \& Sons Ltd.: 239-249.
Onocha P.A., Ajaiyeoba E.O., Dosumu O.O., Ekundayo O. (2005) Phytochemical screening and biological activities of Gomphrena celosioides (C. Mart) extracts. J. Nigerian Soc. Exp. Biol. 5(2): 61-67.

Pan S., Wu S. (2014) Cellulase-assisted extraction and antioxidant activity of the polysaccharides from garlic. Carbohydr. Polym. 111: 606-609.

Puri M., Sharma D., Barrow C.J. (2012) Enzyme-assisted extraction of bioactives from plants. Trends Biotechnol. 30: 37-44.

Qian Z.Q. (2014) Cellulase-assisted extraction of polysaccharides from Cucurbita moschata and their antibacterial activity. Carbohydr. Polym. 101: 432-434.

Quoc L.P.T. (2019) Effect of the assistance of microwave and oxalic acid on the extraction yield of pectin from pomelo (Citrus maxima) peel. Bulgarian J. Agric. Sci. 25(1): 192-196.

Quoc L.P.T., Muoi N.V. (2015) Effects of treatment methods on total polyphenol content and antioxidant activity of Polygonum multiflorum Thunb. root extract. Ann. Food Sci. Technol. 16(1): 78-84.

Rostami H., Gharibzahedi S.M.T. (2017) Cellulase-assisted extraction of polysaccharides from Malva sylvestris: process optimization and potential functionalities. Int. J. Biol. Macromol. 101: 196-206.

Thuy N.T.N., Dieu N.N.Y., Dung T.T.M., Hau T.H., Hai T.C. (2020a) Cellulase-assisted extraction of the total triterpenoid saponins from Polyscias fruticosa (L.) Harms. leaves. Ind. Trade Mag. 1(1): 337-341.

Thuy N.V., Tien N.M., Quy N.N., Lam T.D., Linh H.T.K., Trieu L.H., Minh L.V., Quan P.M., Bui L.M., Truc T.T., Muoi N.V. (2020b) Evaluation of phytochemical and antioxidant activity of Gomphrena celosioides Mart. grown in Tien Giang province, Vietnam. Asian J. Chem. 32: 255-259.

Tiwari A.K., Geed S.R., Singh R.S., Rai B.N. (2014) Extraction of essential oil from Gomphrena celosioides by green separation technology. Int. J. Basic Appl. Biol. 2(2): 18-22.

Vasconcelos P.C.P., Spessotto D.R., Marinho J.V., Salvador M.J., Junior A.G., Kassuya C.A.L. (2017) Mechanisms underlying the diuretic effect of Gomphrena celosioides Mart. (Amaranthaceae). J. Ethnopharmacol. 202: 85-91.

Wijesinghe W.A.J.P., Jeon Y.J. (2012) Enzyme-assistant extraction (EAE) of bioactive components: A useful approach for recovery of industrially important metabolites from seaweeds: a review. Fitoterapia 83: 6-12. 